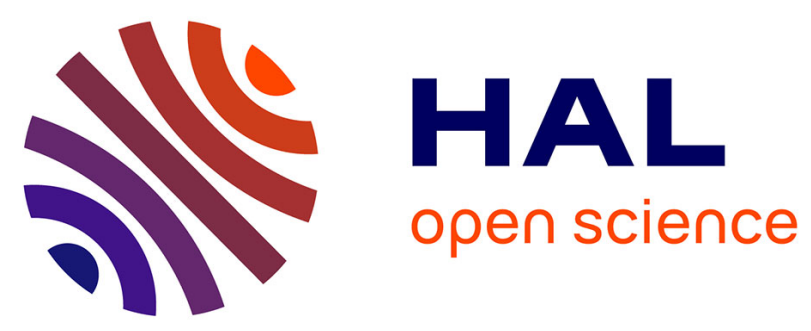

\title{
Organic matter and clay interaction in a meromictic lake: Implications for source rock OM preservation (Lac Pavin, Puy-de-Dôme, France)
}

Adoum Mahamat Ahmat, Mohammed Boussafir, Claude Le Milbeau, Régis Guégan, Tiago de Oliveira, Lydie Le Forestier

\section{To cite this version:}

Adoum Mahamat Ahmat, Mohammed Boussafir, Claude Le Milbeau, Régis Guégan, Tiago de Oliveira, et al.. Organic matter and clay interaction in a meromictic lake: Implications for source rock OM preservation (Lac Pavin, Puy-de-Dôme, France). Organic Geochemistry, 2017, 109, pp.47-57. 10.1016/j.orggeochem.2017.03.014 . insu-01505079

\section{HAL Id: insu-01505079 \\ https://hal-insu.archives-ouvertes.fr/insu-01505079}

Submitted on 11 Apr 2017

HAL is a multi-disciplinary open access archive for the deposit and dissemination of scientific research documents, whether they are published or not. The documents may come from teaching and research institutions in France or abroad, or from public or private research centers.
L'archive ouverte pluridisciplinaire HAL, est destinée au dépôt et à la diffusion de documents scientifiques de niveau recherche, publiés ou non, émanant des établissements d'enseignement et de recherche français ou étrangers, des laboratoires publics ou privés.

\section{(1) (1) $\$$}

Distributed under a Creative Commons Attribution - NonCommercial - NoDerivatives 44.0 


\section{Accepted Manuscript}

Organic matter and clay interaction in a meromictic lake: Implications for source rock OM preservation (Lac Pavin, Puy-de-Dôme, France)

Adoum Mahamat Ahmat, Mohammed Boussafir, Claude Le Milbeau, Régis Guégan, Tiago De Oliveira, Lydie Le Forestier

PII:

S0146-6380(17)30213-9

DOI: http://dx.doi.org/10.1016/j.orggeochem.2017.03.014

Reference: OG 3533

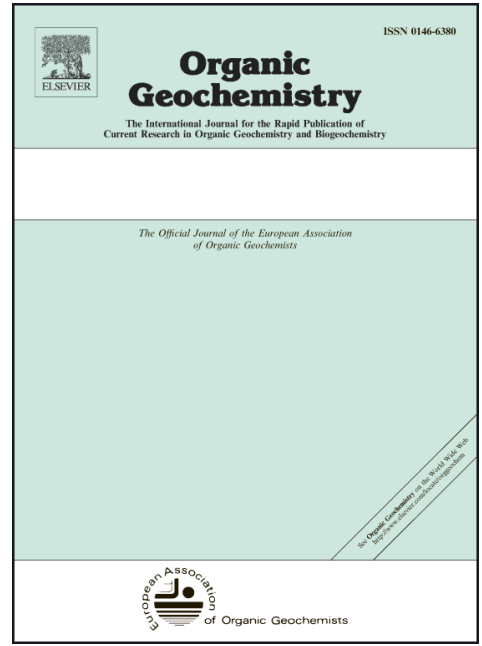

To appear in:

Organic Geochemistry

Received Date:

25 July 2016

Revised Date:

17 March 2017

Accepted Date:

28 March 2017

Please cite this article as: Mahamat Ahmat, A., Boussafir, M., Le Milbeau, C., Guégan, R., De Oliveira, T., Le Forestier, L., Organic matter and clay interaction in a meromictic lake: Implications for source rock OM preservation (Lac Pavin, Puy-de-Dôme, France), Organic Geochemistry (2017), doi: http://dx.doi.org/10.1016/j.orggeochem. 2017.03.014

This is a PDF file of an unedited manuscript that has been accepted for publication. As a service to our customers we are providing this early version of the manuscript. The manuscript will undergo copyediting, typesetting, and review of the resulting proof before it is published in its final form. Please note that during the production process errors may be discovered which could affect the content, and all legal disclaimers that apply to the journal pertain. 


\section{Organic matter and clay interaction in a meromictic lake: implications} for source rock OM preservation (Lac Pavin, Puy-de-Dôme, France)

Adoum Mahamat Ahmat ${ }^{\mathrm{a}, \mathrm{b}, \mathrm{c}^{*}}{ }^{1}$, Mohammed Boussafir ${ }^{\mathrm{a}, \mathrm{b}, \mathrm{c}}$, Claude Le Milbeau ${ }^{\mathrm{a}, \mathrm{b}, \mathrm{c}}$, Régis Guégan $^{\text {a,b,c }}$, Tiago De Oliveira ${ }^{\text {a,b,c }}$, Lydie Le Forestier ${ }^{\text {a,b,c }}$.

a Université d'Orléans, Institut des Sciences de la Terre d'Orléans (ISTO), UMR 7327, 45071 Orléans, France

${ }^{\mathrm{b}}$ CNRS/INSU, ISTO, UMR 7327, 45071 Orléans, France

${ }^{\mathrm{c}}$ BRGM, ISTO, UMR 7327, BP 36009, 45060 Orléans, France

\section{ABSTRACT}

Investigation of organic matter (OM) preservation mechanisms is crucial for understanding organic accumulation in sedimentary environments. We focus here on the contribution of organo-clay interaction in such preservation. Most studies addressing this issue deal with organo-mineral complexes which have settled, omitting consideration of early aggregation within the water column. We therefore investigated the sorption of OM on montmorillonite (Na MMt) and kaolinite (Kaol) immersed in a permanently stratified water column (Lake Pavin, France). The two types of clay samples were kept immersed for different lengths of time and characterized via analytical methods suited for the organic phase [pyrolysis-gas chromatography-mass spectrometry (Py-GC-MS), GC-MS, Fourier transform infrared spectroscopy (FT-IR) and dissolved organic carbon (DOC) analysis, as well as for the mineral phase [X ray diffraction (XRD) and microprobe elementary cartography]. Results suggest that strong organo-clay interaction occurred within the water column to a varying extent depending on water physicochemical conditions and the mineral phase typology. A higher concentration of DOC was observed in the proximal environment of the clay traps, suggesting an attractive effect induced by the clay minerals. Lipid compounds sorbed during the immersion were essentially fatty acids and aromatic compounds. Their distributions were closer to a phytoplankton signature than allochtonous pedogenetic OM.

The sorption was particularly efficient in the $\mathrm{O}_{2}$ transition zone, with a greater amount of $\mathrm{OM}$ on Na-MMt than Kaol. This was principally due to the high specific surface area and cationic exchange capacity (CEC) of the $2 / 1$ clay mineral. Besides, XRD characterization revealed an

\footnotetext{
* Corresponding author. E mail address: adoum.mahamat-ahmat@etu.univ-orleans.fr (A. Mahamat-Ahmat)
} 
increase in $\mathrm{Na}$ MMt interlayer spacing, which did not necessarily correspond to organic intercalation.

The study confirms that the sorption of dissolved OM cannot alone explain the preservation of hydrocarbon-rich $\mathrm{OM}$ in such a lacustrine environment. Indeed, the sorbed OC was very low compared with the amount proposed by several authors as an expression of the monolayer equivalent principle.

\section{Introduction}

Organic Matter (OM) preservation and burial mechanisms in sedimentary environments are still debated, despite the importance they have in oil source rock formation, biomarker fossilization and carbon cycle issues. At the water/sediment interface, OM preservation has been investigated through several approaches: $\mathrm{O}_{2}$ exposure time (Keil and Cowie, 1999; Mayer, 2004; Keil and Mayer, 2014; Hernandez-Sanchez et al., 2014), inherited bioresistance (Largeau et al., 1984; Mayer, 2004), natural sulfurization (Tegelaar et al., 1989; Sinninghe Damsté et al, 1990; Boussafir et al., 1995; Werne et al., 2000; van Dongen et al., 2003, 2006), biodegradation of biopolymers and hetero-polycondensation (Tissot and Welte, 1984) and iron oxide/hydroxide co-precipitation (Eglinton, 2012; Lalondes et al., 2012). The extensive occurrence of $\mathrm{OM} /$ mineral phase association in recent marine sediments and in mature and immature source rocks, led to the hypothesis that sorption onto mineral phases significantly promotes OM preservation (Hedges and Keil, 1995). It is now assumed that OM preservation in sediments arises from the combination of the above mechanisms, whose importance depends on the bio-resistance of the produced $\mathrm{OM}$ and the physico-chemical characteristics of the water column, as well as the sedimentation rate. These parameters depend on the sub-aquatic morphology and the depth of the sedimentary basin in question.

Studies of the mechanism of mineral protection have been motivated by the observation for many depositional systems of a significant correlation between OM content and the specific surface area of the mineral fraction (Keil et al., 1994; Mayer, 1994 a,b), suggesting the important role of grain size and associated specific surface area during the sorption process. Indeed, the finest mineral phase, especially clay, is recognized as the most efficient sorbent. In addition to granulometry, the importance of mineralogy has also been mentioned, highlighting the role of physico-chemical properties, notably the cationic exchange capacity (CEC) of phyllosilicate micro-particles (Drouin et al., 2010). Besides, the 
intrinsic features of the OM, such as degree of cyclization and presence of polar functionalities enhance the sorption rate by promoting strong bonding (Drouin et al., 2010; Mahamat-Ahmat et al., 2016).

On a molecular scale, diverse physical and chemical bonding mechanisms have been proposed to explain the linking of organic compounds to clay minerals: hydrophobic effects, $\mathrm{H}$ bonding, cation bridges, ligand and ion exchange and Van der Waal effects (Arnarson and Keil, 2000; Keil and Mayer, 2014). Low energy bonding, such as Van der Waal effects, hydrophobic effects and $\mathrm{H}$ bonding are reversible (Plante et al., 2005; Lutzow et al., 2006), while cationic bridges and ligand and ion exchange are considered stable, thereby allowing effective protection (Arnarson and Keil, 2000; Drouin, 2007). The relative importance of the mechanisms depends on the organic functional groups, environmental parameters like temperature, $\mathrm{pH}$ and the concentration of cationic elements (Arnarson and Keil, 2000). Among them, metallic ions play a significant catalytic role during sorption (Cervini-Silva et al., 2000; Saidy et al., 2013). In addition to simple surface sorption, other studies have suggested that encapsulation into micro pore and nano pore spaces can also prevent bacterial enzyme access, aiding the preservation of "metabolizable" OM (Kaiser and Guggenberger, 2007; Curry et al., 2007; Mayer,2004). Others suggest that OM intercalation in expandable clay interlayer spaces is also an effective preservation mechanism (Kennedy al., 2002; Kennedy and Wagner, 2011; Arndt and Jorgensen, 2013).

Most of the studies dealing with the issue of mineral sorption for OM preservation do not consider its occurrence during the water column transfer. Mineral protection models have been proposed for settled OM (Suess, 1973; Mayer, 1994a; Ransom et al., 1998; Keil and Cowie 1999; Keil and Mayer, 2014), without taking account of interaction occurring during the period of sedimentation. There is in fact a gap in the understanding of the fate of OM between the senescence of biological producers and sedimentary integration. We aimed to study the process of OM/clay aggregation interaction in the water column of a permanently stratified lake (Lake Pavin, France). In this analogue of a sedimentary euxinic environment, surface water is oxygenated and the lake is subject to seasonal mixing, while the deep zone is stable and permanently anoxic (Michard et al., 1994; Albéric et al., 2013; Cosmidis et al., 2014). Stratification involves changing the physico-chemical conditions in the water column, permitting a study of organo-clay aggregation in different redox conditions. OM-clay interaction experiments were performed using natural montmorillonite and kaolinite immersed at 3 conditions of oxygenation in order to understand the role of clay minerology 
and the influence of different water column physico-chemical conditions on the sorption process.

Prior to performing in situ OM-clay interaction experiments, authigenic organic sources (diatoms and cyanobacteria) and possible pedological OM sources were characterized in order to identify the major lipid contributor pool in the sorption processes.

\section{Material and methods}

\subsection{Study site}

Lake Pavin (Puy de Dôme, France) is a volcanic lake generated after a primary explosive eruption and consecutive phreato-magmatic phases (Bourdier, 1980; Boivin et al., 2011). The maximum depth is $92 \mathrm{~m}$ (Chapron et al., 2010), with an oxygenated upper zone (0-52 m), subject to winter water mixing, and a permanently anoxic deep zone (52-92 m; Viollier et al., 1997; Michard et al., 1994). The $\mathrm{O}_{2}$ profile has its highest value at ca. $15 \mathrm{~m}$ and decreases continuously before reaching total anoxia at ca. $60 \mathrm{~m}$ (Drouin, 2007; Cosmidis et al., 2014). Deep cold water input sustains this meromictic system (Bonhomme et al., 2011).

\subsection{Soil sampling and water column in situ experiments}

\subsubsection{Sampling and in situ experiments}

Soil samples (10) were taken every $310 \mathrm{~m}$ around the lake from $10 \mathrm{~cm}$ depth (Fig.1) and dried at $50{ }^{\circ} \mathrm{C}$ for two days. The soil sampling spots were located at ca. $25 \mathrm{~m}$ from the lake edge. Water samples were taken every $10 \mathrm{~m}$ down the water column in order to characterize dissolved organic carbon (DOC) variation. Natural smectite used was the SWy-2 Wyoming montmorillonite (Na MMt) supplied by the Source Clay Minerals Repository of the Clay Minerals Society. The kaolinite (Kaol) was from the same provider. The $\mathrm{Na}$ MMt and Kaol samples were first treated with $\mathrm{H}_{2} \mathrm{O}_{2}$ and $\mathrm{HCl}$ to remove residual $\mathrm{OM}$ and carbonate. Cylindrical clay containers (36) made for previous experiments (Drouin, 2007) were used as in situ traps. Both sides of the containers were edged with porous membranes $(0.45 \mu \mathrm{m})$. Each sterile trap contained one clay type $(150 \mathrm{mg})$ and Milli-Q water $(30 \mathrm{ml})$ was added before immersion.

Immersion depths $(15,55$ and $80 \mathrm{~m})$ were chosen according to the dissolved $\mathrm{O}_{2}$ profiles and corresponded respectively to oxic, redox front and anoxic zones. The clay traps and blanks were immersed for 6,12, 24 and $48 \mathrm{~h}$. Afterwards, the traps were removed and the clay collected after immediate centrifugation at $5000 \mathrm{rpm}$ for $10 \mathrm{~min}$. Separated aqueous and 
solid phases were kept cold $\left(4{ }^{\circ} \mathrm{C}\right)$. The aqueous phase was stabilized with $\mathrm{H}_{3} \mathrm{PO}_{4}$. Experiments were conducted in April 2014 following the low organic productivity winter period and repeated in July 2014 during the summer algal bloom period.

\subsection{Analytical methods}

\subsubsection{Soil analysis}

Soil lipids were extracted using accelerated solvent extraction (ASE 200, Dionex@) with $\mathrm{CH}_{2} \mathrm{Cl}_{2}: \mathrm{MeOH}(9: 1 \mathrm{v} / \mathrm{v})$ at $100{ }^{\circ} \mathrm{C}$ and 1000 psi. The extract was separated into neutral, acidic and polar fractions using solid phase extraction on aminopropyl bonded silica (Logan and Eglinton, 1994; Jacob et al., 2005). The neutral fraction was silylated by reaction with 80 $\mu 1$ NO-bis(trimethylsilyl)trifluoroacetamide (BSTFA) in $120 \mu 1$ pyridine at $60{ }^{\circ} \mathrm{C}$ for $1 \mathrm{~h}$. The acid fraction was methylated with anhydrous $\mathrm{MeOH} / \mathrm{MeCOCl}$ by heating at $55^{\circ} \mathrm{C}$ for $1 \mathrm{~h}$. An internal standard ( $5 \alpha$-cholestane, $100 \mu \mathrm{l}$ ) was added to each fraction for quantification. Both silylated and esterified fractions were analyzed using gas chromatography-mass spectrometry (GC-MS; Trace GC Ultra equipped with AS 3000 autosampler and coupled to a TSQ Quantum XLS mass spectrometer; Thermo-Scientific, Bremen, Germany). The GC instrument was fitted with a TG-5 MS column (60 m, $0.25 \mathrm{~mm}$ i.d., $0.25 \mu \mathrm{m}$ film thickness) from Thermo®. The oven temperature program was $40{ }^{\circ} \mathrm{C}(1 \mathrm{~min})$ to $120{ }^{\circ} \mathrm{C}$ at $30{ }^{\circ} \mathrm{C} / \mathrm{min}$ and then to $300{ }^{\circ} \mathrm{C}$ (held $46 \mathrm{~min}$ ) at $3^{\circ} \mathrm{C} / \mathrm{min}$. Each sample ( $\left.2 \mu \mathrm{l}\right)$ was injected in splitless mode at $280{ }^{\circ} \mathrm{C}$ and $\mathrm{He}$ was the carrier gas at $1.0 \mathrm{ml} / \mathrm{min}$. The MS instrument was operated in electron ionization (EI) mode at $70 \mathrm{eV}$ and scanned from $\mathrm{m} / \mathrm{z} 50$ to 600 .

\subsubsection{Microalgae analysis}

Lipids were extracted from a mixture of diatoms and cyanophycea sampled from the superficial photic zone of the water column $(2 \mathrm{~m})$. The samples were harvested along a stable cable previously immersed. Organic solvent soluble compounds were extracted from dried algae (492 mg) following a modified Bligh and Dyer (1959) method where $\mathrm{CHCl}_{3}$ had been substituted with $\mathrm{CH}_{2} \mathrm{Cl}_{2}$ and base hydrolysis was performed on the resistant residue. The extract was separated into neutral, acid and polar fractions as described in the previous section. Neutral and acid fraction were analyzed using the same GC-MS device and temperature program as used for soil extract analysis.

\subsubsection{Water column DOC analysis}


DOC concentration was determined using a Shimadzu(C TOC 5000A total organic carbon analyzer, which is a high temperature catalytic oxidation type of device with infrared detection and equipped with an ASI 5000A 20 auto sampler.

\subsubsection{Immersed clay characterization}

\subsubsection{Molecular analysis of sorbed compounds}

Sorbed lipids were analyzed using a CDS Pyroprobe 5150. An aliquot of sample (15 $\mathrm{mg}$ ) was placed in a quartz tube $(1.5 \mathrm{~mm} \times 2 \mathrm{~cm})$. Tetramethylammonium hydroxide (TMAH; 2 in $\mathrm{MeOH} ; 30 \mu \mathrm{l})$ and $10 \mu \mathrm{l}$ of the internal standard ( $5 \alpha$-cholestane, $96 \mathrm{mg} / \mathrm{l})$ were added and the mixture kept at room temperature for $12 \mathrm{~h}$. Pyrolysis (Py) was carried out at $650{ }^{\circ} \mathrm{C}$ for 30 $\mathrm{s}$, with a heating rate of $20^{\circ} \mathrm{C} / \mathrm{ms}$. The transfer line was maintained at $300{ }^{\circ} \mathrm{C}$. For Py-GCMS, a GC-TRACE ${ }^{\circledR}$ (THERMOQUEST $\left.{ }^{\circledR}\right)$ chromatograph coupled to a POLARIS Q $\left(\right.$ FINNIGAN $^{\circledR}$ ) mass spectrometer was used. A RESTEK RTX-5Sil MS column $(30 \mathrm{~m}$, $0.25 \mathrm{~mm}$ i.d, $0.25 \mu \mathrm{m}$ film thickness and $5 \mathrm{~m}$ guard column) was used with He as carrier gas $(1 \mathrm{ml} / \mathrm{min})$. Electron ionization at $70 \mathrm{eV}$ was used with a scan range of $\mathrm{m} / \mathrm{z}$ 50-600. Compounds amounts were quantified using the following relation: $Q_{(\mathrm{x})}=\left[\left(\mathrm{A}_{(\mathrm{x})} / \mathrm{A}_{(\mathrm{Std})}\right) \times \mathrm{m}\right.$ $(\mathrm{std})] / \mathrm{m}_{\text {(samp) }}$

With $\mathrm{Q}_{(\mathrm{x})}$ : Concentration of a given molecule $(\mathrm{x})$ expressed in $\mu \mathrm{g} / \mathrm{g}$ of sample.

$\mathrm{A}_{(\mathrm{X})}$ : Peak area of the molecule $(\mathrm{x})$ on the chromatogram (dimensionless).

$\mathrm{A}_{(\mathrm{Std})}$ : Peak area of the internal standard on the chromatogram (dimensionless).

$\mathrm{m}_{\text {(std) }}$ : Internal standard mass $(\mu \mathrm{g})$

$\mathrm{m}_{\text {(samp): }}$ Pyrolysed sample mass (g)

\subsubsection{XRD analysis of OM-clay aggregates}

The $\mathrm{d}_{001}$ spacing of the immersed clays was determined from the first 001 reflection from the X-ray diffraction patterns, which were recorded with a conventional $\theta-\theta$ BraggBrentano configuration. A Thermo Electron ARL'XTRA diffractometer equipped with a $\mathrm{Cu}$ anode $\left(\mathrm{Cu} \mathrm{K} \mathrm{K}_{\alpha 1,2}=1.5418 \AA\right)$ coupled to a $\mathrm{Si}(\mathrm{Li})$ solid detector was used. The X-ray diffractograms from dry samples $\left(100{ }^{\circ} \mathrm{C}, 24 \mathrm{~h}\right)$ were performed between 1 and $26^{\circ}(2 \theta)$ with an angular step and time step of $0.04^{\circ}$ and 10 s respectively.

\section{Results}

\subsection{Organic source characterization}


The sampled wmicroalgae were principally diatoms and cyanobacteria. The neutral fraction of each lipid extract was composed of sterols, isoprenoids and $n$-alkanes (cf. Supplementary data), among which cholesterol, phytone and octacosane were the most abundant. The acid fraction was composed principally of saturated fatty acids (FAs; Fig.2B), characterized by the classic predominance of hexadecanoic and octadecanoic acids. The neutral fraction of the soil extracts showed the presence of triterpenoids, sterols, aliphatic alcohols and $n$-alkanes of various chain lengths (cf. supplementary data). The relative abundance varied according to the vegetation around the lake, which is dominated by Betula pubescens and Pinaceae. Docosanoic acid $\left(\mathrm{C}_{22}\right)$ was the most abundant FA in soil extracts (Fig. 2A and 2A'), providing a different signature from the distribution of microalgal lipids.

\subsection{DOC evolution}

DOC analysis of water samples allowed determination of OC evolution every $10 \mathrm{~m}$ (Fig. 3). The DOC profile had a slight increase at ca. $20 \mathrm{~m}$, where photosynthetic activity was usually intensive. At this depth, different molecular and particulate biodegradation products such as metabolic exudates and senescent organisms led to an increase in DOC concentration. Deeper, at ca. $80 \mathrm{~m}$, the high DOC concentration was induced by the diffusion of stored carbon from the underlying sediment. Indeed, at the sediment interface anoxia weakens biodegradation rate, thereby favouring OM accumulation (Albéric et al., 2013; Drouin, 2007), the ascending diffusive flux of which increases DOC.

The concentration of DOC in the photic zone traps was higher than the external natural lacustrine water values (Fig. 3A), suggesting labile OM enrichment within these traps. However, this over-concentration was not noticed for the chambers immersed in the deep zone (transition and anoxic depths). As said above, anoxia prevailing beyond $52 \mathrm{~m}$ lowers $\mathrm{OM}$ degradation rate within the sediment, involving high organic accumulation. Indeed, Schettler et al., (2007) and Chassiot (2015) reported an organic concentration ranging between 3 and $6 \%$ of OC in the sediment, which enriches deep water via DOC ascending fluxes (Albéric et al., 2013). These sedimentary storage effects on the water column can be observed on Fig. 3A, where DOC concentration significantly heightened from $52 \mathrm{~m}$ to the bottom. At $52 \mathrm{~m}$ and deeper, excess of DOC in the lake did not allow interpretation of the role of clay on organic flux within the chambers. In fac,t clay-attracted DOC concentrations cannot exceed the background values in this zone. 
The excess noticed in the photic zone is similar to the trend in lacustrine experiments (Drouin, 2007) and in a marine context (Mahamat Ahmat et al., 2016), confirming the capacity of natural clays to over concentrate $\mathrm{OC}$ from the nearest aqueous environment. The attraction varied with immersion time, physicochemical immersion zone and clay mineralogy. As an example, in the photic zone, OC was over-concentrated for $12 \mathrm{~h}$ and $48 \mathrm{~h}$ of immersion in Na MMt traps, describing an anti-correlation trend compared with the evolution of sorbed amount (Fig. 3B). Water DOC concentration appeared to closely depend on sorption.

\subsection{Organo-clay complex analysis}

\subsubsection{Na MMt sorbed lipids}

Results stressed the sorption of three main lipid groups during clay lacustrine immersion: benzene alkyls, $n$-alkanes and FAs, in addition to a pool of nitrogenous and nonidentifiable compounds (Fig. 4). The benzene compounds were probably produced in the water column by microbial precursors that we did not investigate here. FAs were predominantly sorbed during clay lacustrine immersion, excepting for two times $(6 \mathrm{~h}$ and 12 h, before the algal bloom) where $n$-alkanes and benzene alkyls were mainly sorbed

Labile lipids were sorbed mainly in the transition zone $(55 \mathrm{~m})$, where dissolved Fe concentratio started to increase (Michard et al., 1994). The anoxic zone was less propitious for aggregation (Fig. 5). Our approach showed that the sorbed amount was substantially higher before the algal bloom period. For this period, we also observed, surprisingly, that the shortest interaction time $(6 \mathrm{~h})$ showed the best sorption rate, while no notable hierarchy was observed for the following immersion times: 12, 24 and $48 \mathrm{~h}$. FAs were the most sorbed lipid group (Fig. 6), with a high abundance of hexadecanoic acid $\left(\mathrm{C}_{16}\right)$ and octadecanoic acid $\left(\mathrm{C}_{18}\right.$; Fig.6B). Dodecanoic acid $\left(\mathrm{C}_{22}\right)$, although highly concentrated in the soil extracts, was not represented, foreshadowing an authigenic source for sorbed FAs. Organo-clay interaction was globally less efficient during the algal bloom season, probably as a result of the clay minerals lack of reactivity with the new input of fresh organic molecules to the lacustrine column.

\subsubsection{Sorption on Kaol}

Benzene alkyls, $n$-alkanes and FAs were also the main lipid groups sorbed onto kaolinite samples during immersion (Fig. 4). 
The transition zone $(55 \mathrm{~m})$ was likewise the most efficient for Kaol interaction, with greater sorbed amount before the algal bloom period (Fig. 5). Sorbed lipid amount was clearly less on Kaol than Na MMt, highlighting the relative efficiency of smectites during organoclay aggregation vs. a 1:1 clay. Besides, from a qualitative point of view, FAs were the most reactive group (Fig. 4), with the same high abundance of hexadecanoic acid and octadecanoic acid. Considering immersion time, the results did not point to any significant favorable interaction time. As observed above for $\mathrm{Na} \mathrm{MMt}$, the interaction was less efficient during the post bloom experiments, probably involving the lack of reactivity of freshly inputted compounds.

\subsubsection{Electronic microprobe mapping of metallic elements}

The Pavin water column contains several types of dissolved mineral elements inherited from its magmatic origin and volcanic basement (Michard et al., 1994; Takayangi and Cossa, 2007; Viollier et al., 1997). Among the metallic ones, e.g Fe and Mg were admitted to inducing a catalytic effect during organic compound sorption (Cervini-Silva et al., 2000; Saidy et al., 2013). Electronic microprobe mapping of these elements was performed on clay samples immersed in the transition zone, where $\mathrm{Fe}$ and $\mathrm{Mg}$ concentrations start to considerably increase (Michard et al., 1994; Drouin, 2007). Identical analyses were conducted on a non-immersed Na MMt sample, considered a reference (Fig. 7). The results suggest a significant enrichment of $\mathrm{Al}, \mathrm{Fe}$ and $\mathrm{Mg}$, which were also included in the initial clay composition $\left[(\mathrm{Na}, \mathrm{Ca})_{0.3}(\mathrm{Al}, \mathrm{Fe}, \mathrm{Mg})_{2} \mathrm{Si}_{4} \mathrm{O}_{10}(\mathrm{OH})_{2} \mathrm{nH}_{2} \mathrm{O}\right]$. Ionic exchange probably occurred during electrical charge compensation mechanisms during the immersion, highlighting the high reactivity of $\mathrm{Na} \mathrm{MMt}$ in this environment.

\subsubsection{Swelling of clay minerals}

$\mathrm{X}$ ray diffraction (XRD) analysis was performed on the resultant in-situ organo-clay complexes in order to characterize the interlayer distance fluctuation during time in the water column. Since kaolinite is non-swelling, analysis focused only on the Na MMt samples. The XRD patterns from $\mathrm{Na}$ MMt before immersion showed a $00 l$ reflection $8.88^{\circ}$ (Fig. 8A), corresponding to $10.01 \AA$ for the $\mathrm{d}_{001}$ interlayer spacing. Computer simulation and previous $\mathrm{X}$-ray diffraction experiments showed that swelling of Na-MMt below the osmotic pressure corresponds to four stable states at basal spacing of 9.7, 12.0, 15.5 and $18.3 \AA$, due to the hydration of on 1, 2, 3 and 4 layers of water around the exchangeable $\mathrm{Na}^{+}$ions, respectively (Cadars et al., 2012; Balme et al., 2013). The value of $10.0 \AA$ for the non-immersed Na-MMt 
confirms the dehydration of the samples before XRD. For the immersed clay samples, the XRD patterns exhibited several $00 \mathrm{l}$ reflections at lower angular values than the non-immersed Na-MMt. It is interesting to note a second order of the $00 l$ reflections for the sample with the longest immersion time, which underlines the existence of a good ordering in the silicate layers. This demonstrates intercalation and the formation of ordered structures within the interlayer space of the silicate layers. The expansion of the $d_{001}$ interlayer spacing was observed for all the immersed samples (Fig.8B) and reached an average value of 14.28 and $15.26 \AA$ for the samples immersed for $6 \mathrm{~h}$ and $48 \mathrm{~h}$, respectively.

\section{Discussion}

DOC was concentrated in the clay traps, with values often higher than the water column background concentration (Fig. 3A). This organic influx underlined the ability $\mathrm{Na}$ MMt and Kaol to attract dissolved environmental organic compounds, probably via electrostatic attraction. Indeed, the clay layers are negatively charged, resulting mainly from $\mathrm{Al} / \mathrm{Mg}$ or $\mathrm{Fe}^{3+} / \mathrm{Mg}$ substitutions in the octahedral sheet, which offer possible electrostatic interaction with oppositely charged organic compounds, e.g. amino acids. Besides, incorporated metallic elements (Fig. 7) allow cation bridge interactions. In this case, electrostatic attraction can occur between positive ionic sites and negatively charged organic compounds, i.e. FAs. In fact, due to the basic conditions (pH ca.8) in the upper layers of the water column (Alberic et al., 2013), FAs were in the $\mathrm{COO}^{-}$state.

DOC fluctuation in photic zone traps water was intrinsically associated with a sorption/desorption dynamic, as the clay-sorbed amount evolved in an anti-correlated trend with water DOC concentration (Fig. 3B). The trend highlighted the instability of a portion of sorbed compounds with no polar functionality, such as $n$-alkanes. They cannot develop strong bonding and were probably associated with the clay surface via low energy links such as Van der Waals bonding and $\mathrm{H}$ bonding.

Py-GC-MS performed on the immersed clays showed that sorbed amount was particularly high in the transition zone (Fig. 5), suggesting that this zone was the most propitious for organo-clay interaction. This depth $(55 \mathrm{~m})$ was also the place where the redox front had been located (Cosmidis et al., 2014). Dissolved metallic element concentration (Fe, $\mathrm{Al}, \mathrm{Mg}, \mathrm{Mn}$ ) started to rise considerably in this zone, adopting the reduced forms (Michard et al., 1994; Viollier et al., 1997) favored by rising anoxia (Drouin, 2007). These elements had probably been incorporated into clay crystallographic networks via ionic exchange, leading to 
the enrichment in microprobe mapping (Fig. 7). Batch experiments and field approaches demonstrated that the presence of metallic elements enhances organo-clay association (Cervini-Silva et al., 2000; Saidy et al., 2013), underlining in particular the great catalytic effect of dissolved Fe and Fe carrier phases.

So, the sorption in the transition zone samples was probably driven by the presence of precipitated and dissolved catalytic elements. Particular physicochemical conditions prevailing at the oxic-anoxic transition zone involved the formation of oxy-hydroxide flocks and organo-metallic complexes increasing water turbidity at this depth (Cosmidis et al., 2014). These conditions probably amplified the OM sorption, which explains the large sorbed amount noticed in this zone of the water column. Supplementary factors, such as the decrease in $\mathrm{pH}$ and the cold temperature at this depth (Assayag et al., 2008; Albéric et al., 2013) also enhanced sorption and contributed to the high sorption rate. These parameters are indeed known to favor organic sorption on clay minerals (Arnarson and Keil, 2000; Keil and Mayer, 2014).

Photosynthetic organic input to the upper layers and stored carbon diffusion from the bottom enriched DOC concentration respectively in the photic $(20 \mathrm{~m})$ and anoxic $(80 \mathrm{~m})$ zones, conferring on them higher organic values vs. the transitional zone (Fig. 3). However, the sorbed amounts were greater on the clay samples immersed in the transition zone (Fig.5). This excluded, de facto, organic availability as a controlling parameter during the sorption process and highlighted the preponderant role of the redoxcline position.

In addition, analysis of pelagic microalgae (cf. Supplementary data), littoral macrophytes (Drouin, 2007) and soil extractable lipids showed a wide diversity of compounds potentially soluble in the water. GC-MS demonstrated that these 3 organic pools produced varied compounds such as isoprenoids, triterpenoids, sterols, stanols and aliphatic alcohols, which were not involved in organo-clay interaction. Py GC-MS conducted on the aggregated organo-clay complexes showed that FAs were the predominant group sorbed, followed by $n$ alkanes. This highlighted selective behavior of the clay minerals. Indeed, they clearly exhibited a greater affinity for these linear molecules vs. isoprenoids and polycyclic compounds also available in the water column. Note that aliphatic alcohols, ubiquitous in the OM sources (cf. Supplementary data), were not sorbed onto the immersed Kaol and Na MMt. This means that linearity was not the only factor required during sorption and underlines the key role of carboxylic functions. 
Among the sorbed FAs (Fig. 6), hexadecanoic and octadecanoic acids were the most common. These two dominant acids are ubiquitous and non-specific. However, the FA distribution was closer to that in the autochthonous phytoplankton from the water column (Fig 2B) than to the surrounding soil watershed. In addition, the clay sorbed FA distribution lacked docosanoic acid, the most represented acid in the soil extracts (Fig. 2A and 2A'). This confirms the algal influence on the sorbed OM. Nevertheless, a slight difference was observed between algal FA distribution and sorbed FA distribution. Contrary to the planktonic distribution (Fig. 2B), octadecanoic acid concentration was higher than that of hexadecanoic acid in the organo-clay complexes (Fig. 6). Thus, the clay sample probably had a second order of selectivity, favoring a specific carbon length among the FAs. In vitro experiments are necessary to demonstrate this hypothesis.

Overall, Na MMt exhibited higher sorption rate than Kaol (Fig. 6), confirming the hierarchy observed in a marine context (Mahamat Ahmat et al., 2016) and in batch experiments (Feng et al., 2005), whereby 2:1 clays were more efficient than 1:1 clays. Physical characteristics, such as specific area and CEC differences could explain such heterogeneous behavior during sorption. Indeed, $\mathrm{Na} \mathrm{MMt}$, with a large surface specific area (Table 1), enhances sorption rate by way of numerous accessible sites (Keil and Mayer, 2014), and the high CEC value promotes physico-chemical interaction mechanisms such as cation bridging and/or ligand exchange (Drouin et al., 2010). Besides, organic sorption on $\mathrm{Na}$ MMt was possibly enhanced by way of possible exfoliation from, or a large opening in the interlayer space. XRD results showed a significant increase in the $\mathrm{d}_{001}$ interlayer spacing (Fig. 8) during immersion in the lake, suggesting intercalation of dissolved compounds. Yet, this contribution was probably quantitatively low, as inorganic compounds like dissolved metals and metalloids ( $\mathrm{Al}, \mathrm{Fe}, \mathrm{Mg}, \mathrm{Mn}, \mathrm{Sb} . .$.$) inherited from the magmatic genesis at the site$ (Michard et al., 1994; Viollier et al., 1997; Takayanagi and Cossa, 2007) were probably also incorporated in the interlayer spaces by way of exchange mechanisms (i.e. cationic exchange). These elements, with high electronegativity, might be more competitive than organic molecules for intercalation, suggesting that sheet edges and external surfaces were the main accessible adsorption sites involved in the adsorption of OM.

The total amount of OC sorbed on both montmorillonite and kaolinte was comparable to that sorbed in a marine water column using a similar in situ experimental approach (Mahamat-Ahmat et al., 2016). Indeed, for the same immersion time (24 h), the richest samples had ca.700 $\mu \mathrm{g} / \mathrm{g}$ of organic compounds in both contexts, representing $0.07 \%$ of the 
organo-clay complexes. These values are clearly inferior to those found at sediment interfaces. Indeed, TOC measurements of Pavin sediments highlighted a TOC value of $6 \%$ (Schettler et al., 2007), while 2\% was measured for recent Antofagasta Bay sediments (Niggemann et al., 2007). Pavin basin configuration and productivity explain the higher TOC values than for the upwelling zone sediments. Its restricted sedimentary interface leads to OM accumulation. In all types of environment, a huge difference exists between the suspended $\mathrm{OM}$ in the water column and the preserved $\mathrm{OM}$ in sediments. This suggests that intra column sorption alone cannot explain sedimentary OM preservation, implying further mechanisms assisting $\mathrm{OM}$ burial. Processes such as natural sulfurization occurring in the anoxic zone (Sinninghe Damsté and de Leeuw, 1990; Boussafir et al., 1995; Boussafir and Lallier-Vergès, 1997), which make natural OM recalcitrant to benthos assimilation, play a preponderant role. Other pathways, such as the selective preservation of bio-resistant OM (Largeau et al., 1986; Riboulleau et al., 2001; Mayer, 2004), the polycondensation phenomenon leading to recalcitrant geopolymers (Tissot and Welte, 1984), as well as iron oxide co-precipitation (Eglinton, 2012; Lalondes et al., 2012), should be considered. They confer steric protection, contributing to the global preservation of aliphatic rich material, thereby allowing its later thermal evolution.

Furthermore, this study has shown again that the sorption of dissolved OM is alone insufficient to explain the monolayer equivalent (ME) theory described by Mayer (1994a) or Hedges and Keil (1995). Our results are far from the expected 0.5 to $0.8 \mathrm{mg} / \mathrm{m}^{2}$ of OM sorbed onto mineral surface area proposed via the ME. Sedimentary OM described by the ME model is certainly preserved, but also with the participation of other mechanisms. The ME coating was probably reached because the role of clay minerals was twofold: (i) Adsorption affecting both the dissolved fraction and organic aggregates formed by biodegradation and polycondensation and (ii) steric shielding. Within the sediment, steric protection prevented OM trapped in mesopores from bacterial and enzymatic degradation. The combination of these two processes may lead to a level of OC in clays as high as that evoked in the ME theory.

\section{Conclusions}

Organo-clay interaction experiments performed in a stratified lacustrine column demonstrated that FAs were the most reactive lipid group. This underlined a selective behavior, as different types of compounds (isoprenoids, sterols, stanols, triterpenoids, 
aliphatic alcohols, etc.) were available in the water column. Acidic $\mathrm{pH}$ prevailing down through the photic zone suggested that FA reactivity was promoted by the difference in electrical potential between their charged function and the clay surface. Interaction was probably enhanced by dissolved metallic elements $(\mathrm{Fe}, \mathrm{Al}, \mathrm{Mg})$, which are reported to be catalysts for organo-clay reactions. The transition zone $(55 \mathrm{~m})$, where previous authors characterized a dramatic increase in metallic and metalloids concentration (Michard et al., 1994; Viollier et al., 1997, Takayangi and Cossa, 2007), was also the most propitious zone for sorption. Association down the water column between natural OM and metallic oxyhydroxides (resulting from the oxidation of reduced metallic elements falling back into the anoxic zone) was probably responsible for the increase in water turbidity in the redox-front area of the lake water column (Cosmidis et al., 2014).

In addition, organic concentration evaluated for the in situ aggregated complexes highlighted the idea that montmorillonites were the most favorable clay type, confirming a hierarchical order observed in batch experiments (Feng et al., 2005) and in a marine water column context (Mahamat Ahmat et al., 2016). Although montmorillonite showed an increase in its interlayer space, no OM was intercalated but was preferentially adsorbed onto both the external surface and edges of the phyllosilicate sheets.

However, the amount of sorbed compounds was relatively low compared with the amount of settled OM. Previous studies reported values of OC oscillating between 3 and $6 \%$ within recent sediments (Schettler et al., 2007; Chassiot, 2015). To explain the preservation the amount of $\mathrm{OM}$ settled in such environments, further concepts relating to preservation, such as inherited resistance, polycondensation and natural sulfurization and the flux of particulate OM have to be considered. We suggest that the concentration of settled OM arises from the combination of these different preservation mechanisms, in addition to the water column protective sorption.

\section{Acknowledgements}

The study was supported by the CESSUR project funded by the French INSU/CNRS (AO2011-b5017). A.M.A benefitted from a Ph.D. grant provided by the Région Centre Valde-Loire, France. We thank Ms Rowley-Jolivet for her linguistic contribution. We are also 
grateful to P.A. Meyers and an anonymous reviewer whose relevant observations helped improve the manuscript

\section{Associate Editor - B. van Dongen}

\section{Figure captions}

Fig. 1. Study site location. Soil sampling strategy and experimental device position.

Fig. 2. Saturated FA distribution in soil (A, A') and microalgae extracts (B).

Fig. 3. DOC in clay traps (side bars) compared with water column DOC profile (continuous line). Fig. B presents sorbed OM amount and DOC concentration in the same trap according to immersion time.

Fig. 4. Main lipid groups sorbed on montmorillonite and kaolinite samples immersed in the photic (PH), transition (TR) and anoxic (AN) zones of the lacustrine column during 6, 12, 24 and $48 \mathrm{~h}$. Graphs on the left present the results obtained before the algal bloom and those on the right represent sorbed amounts during the algal bloom.

Fig. 5. Clay sorbed lipids (vertical bars) vs. immersion zone (PH, photic zone; TR, transition zone; AN, anoxic zone). Dashed lines represent Fe (II) concentration along the water column (data from Michard et al., 1994). The sorption results are shown for before and after algal bloom experiments.

Fig. 6. Sorbed FA distribution on Na MMt and Kaol. Results obtained from before-bloom experiments. A similar distribution was observed for the post-bloom experiments

Fig. 7. EDS element mapping of transition-zone immersed and non-immersed blank samples.

Fig. 8. XRD diffractograms of $\mathrm{Na} M M t$ immersed samples (PH, photic zone; $\mathrm{TR}$, transition zone; AN, anoxic zone) and non-immersed blank samples (NI). Fig. B shows interlayer basal distance $\left(\mathrm{d}_{001}\right)$ for immersed samples and referential one.

\section{Table captions}

Table 1. Experimental clay mineral physico-chemical characteristics (CEC, cationic exchange capacity).

$$
\text { CEC (meq/100 g Specific area }\left(\mathrm{m}^{2} / \mathrm{g}\right)
$$


of clay)

\begin{tabular}{lll}
\hline Na MMt & 85 & 736.8 \\
& & \\
Kaol & 5 & 15 \\
\hline
\end{tabular}

\section{References}

Albéric, P., Jézéquel, D., Bergonzini, L., Chapron, E., Viollier, E., Massault, M., Michard, G., 2013. Carbon cycling and organic radiocarbon reservoir effect in a meromictic crater lake (Lac Pavin, Puy-de-Dôme, France. Radiocarbon 55, 1029-1042.

Arndt, S., Jorgensen, B.B., 2013. Quantifying the degradation of organic matter in marine sediments: A review and synthesis. Earth-Science Reviews 123, 53-86.

Arnarson, T.S., Keil, R.G., 2000. Mechanisms of pore water organic matter adsorption to montmorillonite. Marine Chemistry 71, 309-320.

Assayag, N , Jézéquel, D., Ader, M., Viollier, E ., Michard, G., Prévot, F., Agrinier, P., 2008. Hydrological budget, carbon sources and biogeochemical processes in Lac Pavin (France): Constraints from $\delta^{18} \mathrm{O}$ of water and $\delta^{13} \mathrm{C}$ of dissolved inorganic carbon. Applied Geochemistry 23, 2800-2816.

Balme, S., Guégan, R., Janot, J.M., Jaber, M., Lepoitevin, M., Dejardin, P., Bourrat, X., Motelica-Heino, M., 2013. Structure, orientation and stability of lysozyme confined in layered materials. Soft Matter 9, 3188-3196.

Boivin, P., Besson, J-C., Ferry, P., Gourgaud, A., Miallier, D., Thouret, J-C., Vernet, G., 2011. Le point sur l'éruption du lac Pavin il y a 7000 ans. Revue des Sciences Naturelles de 1'Auvergne 74/75, 45-56.

Bonhomme, C., Poulin, M ., Vinçon-Leite, B., Saad, M., Groleau, A., Jézéquel, D., Tassin, B., 2011. Maintaining meromixis in Lake Pavin (Auvergne, France): The key role of a sublacustrine spring. Comptes Rendus Geoscience 343, 749-759. 
Bourdier, J., L., 1980. Contribution à 1' Etude Volcanologique de Deux Secteurs d'Intérêt Géothermique dans le Mont Dore: Le Groupe Holocène du Pavin et le Massif du Sancy. $\mathrm{PhD}$ Thesis, Université de Clermont-Ferrand II, 180 pp.

Boussafir, M., Gelin, F., Lallier-Vergès, E., Derenne, S., Bertrand, P., Largeau, C., 1995. Electron microscopy and pyrolysis of kerogen from the Kimmeridgian Clay Formation, UK: Source organisms, preservation processes, and origin of the microcycles. Geochimica et Cosmochimica Acta 59, 3731-3747.

Boussafir, M., Lallier-Vergès, E., 1997. Accumulation of organic matter in the Kimmeridge Clay formation $(\mathrm{KCF})$ : an update fossilisation model for marine petroleum sourcerocks. Marine and Petroleum Geology 14, 75-83.

Cadars, S., Guégan, R., Garaga, M. N., Bourrat, X., Le Forestier, L., Fayon, F., Huynh, T-V., Allier, T., Nour, Z., Massiot, D., 2012. New insights into the molecular structures, compositions, and cation distributions in synthetic and natural montmorillonite clays. Chemistry of Materials 24, 4376-4389.

Cervini-Silva, J., Wu, J., Stucki, J.W., Larson, R.A., 2000. Adsorption kinetics of pentachloroethane by iron-bearing smectites. Clays and Clay minerals 48, 132-138.

Chapron, E., Albéric, P., Jézéquel, D., Versteeg, W., Bourdier, J-L., Sitbon J., 2010. Multidisciplinary characterization of sedimentary processes in a recent maar lake (Lake Pavin, French Massif Central) and implication for natural hazards. Natural Hazards and Earth System Sciences 10, 1815-1827.

Chassiot, L., 2015. Forçages Naturels et Anthropiques sur la Sédimentation Holocène des Lacs d'Auvergne et des Réservoirs des Bassins Versants de la Loire et d'AdourGaronne. PhD thesis, Université d'Orléans, 504 pp.

Cosmidis, J., Benzerara, K., Morin, G., Busigny, V., Lebeau, O., Jézéquel, D., Noël, V., Dublet, G., Othmane, G., 2014. Biomineralization of iron-phosphates in the water column of Lake Pavin (Massif Central, France). Geochimica et Cosmochimica Acta 126, 78-96.

Curry, K.J., Bennett, RH., Mayer, LM., Curry, A., Abril, M., Biesiot, P.M., Hulbert, M-H., 2007. Direct visualization of clay microfabric signatures driving organic matter 
preservation in fine-grained sediment. Geochimica et Cosmochimica Acta 71, 17091720.

Derenne, S., Largeau, C. 2001., A review of some important families of refractory macromolecules: Composition, origin, and fate in soils and sediments. Soil Science 166, 833-847.

Drouin, S., 2007. Rôle des Argiles dans la Préservation et la Fossilisation de la Matière Organique Pétroligène. PhD Thesis, Université d'Orléans, 216 pp.

Drouin, S., Boussafir, M., Robert, J. L., Albéric, P., Durand, A., 2010. In vitro experiments of carboxylic acids sorption on synthetic clays in natural marine water. Implication on organic clayey rich sedimentation. Organic Geochemistry 41, 192-199.

Eglinton, T I., 2012. A rusty carbon sink. Nature 483, 165-166.

Feng, X., Simpson, A.J., Simpson, M.J. 2005. Chemical and mineralogical controls on humic acid sorption to clay mineral surfaces. Organic Geochemistry 36, 1553-1566.

Jacob, J., Disnar J-R., Boussafir, M., Spadano Albuquerque, A.L., Sifeddine A., Turcq, B., 2005. Pentacyclic triterpene methyl ethers in recent lacustrine sediments (Lagoa do Caçó, Brazil). Organic Geochemistry 36, 449-461.

Hedges, J. I., Keil, R. G., 1995. Sedimentary organic matter preservation: an assessment and speculative synthesis. Marine Chemistry 49, 81-115.

Hernández-Sánchez, M.T., LaRowe, D.E., Deng, F., Homoky, W.B., Browning, T.J., Martin P., Mills, R., Pancost R.D., 2014. Further insights into how sediment redox status controls the preservation and composition of sedimentary biomarkers. Organic Geochemistry 76, 220-234.

Kaiser, K., Guggenberger, G., 2007. Sorptive stabilization of organic matter by microporous goethite: Sorption into small pores vs. surface complexation. European Journal of Soil Science 58, 45-59.

Kennedy, M.J., Pevear, D.R., Hill, R.J., 2002. Mineral surface control of organic carbon in black shale. Science 295, 657-660. 
Kennedy, M.J., Wagner, T., 2011. Clay mineral continental amplifier for marine carbon sequestration in a greenhouse ocean. Proceedings of the National Academy of Sciences 108, 9776-9781.

Keil, R.G., Cowie, G.L., 1999. Organic matter preservation through the oxygen-deficient zone of the NE Arabian Sea as discerned by organic carbon:mineral surface area ratios. Marine Geology 161, 3-22.

Keil, R.G., Hu, F-S., Tsamakis, E C., Hedges, J I., 1994. Pollen in marine sediments as an indicator of oxidation of organic matter. Nature 369, 639-641.

Keil, R.G., Mayer, L.M., 2014. Mineral matrices and organic matter. Treatise on Geochemistry (Second Edition) 12, 337-359.

Lalonde, K., Mucci, A., Ouellet, A., Gélinas, Y., 2012. Preservation of organic matter in sediments promoted by iron. Nature 483, 198-200.

Largeau, C., Casadevall, E., Kadouri, A., Metzger, P., 1984. Formation of botryococcusderived kerogens. Comparative study of immature torbanites and of the extant alga Botryococcus braunii. Organic Geochemistry 6, 327-332.

Logan, G.A., Eglinton, G., 1994. Biogeochemistry of the Miocene deposit, at Clarika, northern Idaho, U.S.A. Organic Geochemistry 21, 857-870.

Lutzow, M., Kögel-Knabner, I., Ekschmitt, K., Matzner, E., Guggenberger, G., Marschner, B., Flessa, H., 2006. Stabilization of organic matter in temperate soils: Mechanisms and their relevance under different soil conditions-A review. European Journal of Soil Science 57, 426-445.

Mahamat-Ahmat, A., Boussafir, M., Le Milbeau, C., Guégan, R., Valdès, J, Guiñez, M., Sifeddine, A., Le Forestier, L., 2016. Organic matter-clay interaction along a seawater column of the Eastern Pacific upwelling system (Antofagasta bay, Chile): implications for source rock organic matter preservation. Marine Chemistry 179, 23-33.

Mayer, L.M., 1994a. Surface area control of organic carbon accumulation in continental shelf sediments. Geochimica et Cosmochimica Acta 58, 1271-1284.

Mayer, L.M., 1994b. Relationships between mineral surfaces and organic carbon concentrations in soils and sediments. Chemical Geology 114, 347-363. 
Mayer, L.M., 2004. The inertness of being organic. Marine Chemistry 92, 135-104.

Michard, G., Viollier, E., Jezequel, D., Sarazin, D., 1994. Geochemical study of a crater lake: Pavin Lake, France. Identification, location and quantification of the chemical reactions in the lake. Chemical Geology 115, 103-115.

Niggemann, J., Ferdelman, T.G., Lomstein, B.Aa., Kallmeyer, J., Schubert, C-J., 2007. How depositional conditions control input, composition, and degradation of organic matter in sediments from the Chilean coastal upwelling region Geochimica et Cosmochimica Acta 71, 1513-1527.

Plante, A.F., Pernes, M., Chenu, C., 2005. Changes in clay-associated organic matter quality in a $\mathrm{C}$ depletion sequence as measured by differential thermal analyses. Geoderma 129 , 186-199.

Ransom, B., Kim, D., Kastner, M., Wainwright, S., 1998. Organic matter preservation on continental slopes: Importance of mineralogy and surface area. Geochimica et Cosmochimica Acta 62, 1329-1345.

Riboulleau, A., Derenne, S., Largeau, C., Baudin, F., 2001. Origin of contrasting features and preservation pathways in kerogens from the Kashpir oil shales (Upper Jurassic, Russian Platform). Organic Geochemistry 32, 647-665.

Salmon, V., Derenne, S., Lallier-Vergès, E., Largeau, C., Beaudoin, B., (2000) Protection of organic matter by mineral matrix in a Cenomanian black shale. Organic Geochemistry $31,463-474$.

Saidy, A.R., Smernik, R.J., Bladock, J.A., Kaiser K., Sanderman, J., 2000 The sorption of organic carbon onto differing clay minerals in the presence and absence of hydrous iron oxide. Geoderma 209-210, 15-21.

Schettler, G., Schwab, M.J., Stebich, M., 2007. A 700-year record of climate change based on geochemical and palynological data from varved sediments (Lac Pavin, France). Chemical Geology 240, 11-35.

Sinninghe Damsté, J.S., de Leeuw, J.W., 1990. Analysis, structure and geochemical significance of organically-bound sulphur in the geosphere: state of the art and future research. Organic Geochemistry 16, 1077-1101. 
Suess, E., 1973. Interaction of organic compounds with calcium carbonate 2. Organocarbonate associations in recent sediments. Geochimica et Cosmochimica Acta. 37, 2435-2447.

Takayangi, K., Cossa D., 2007.Vertical distribution of $\mathrm{Sb}(\mathrm{III})$ and $\mathrm{Sb}(\mathrm{V})$ in Pavin lake, France. Water Research 31, 671-674.

Tegelaar, E.W., de Leeuw,J.W., Derenne S., Largeau C., 1989. A reappraisal of kerogen formation. Geochimica et Cosmochimica Acta 53, 3103-3106.

Tissot, B.P., Welte, D.H., 1984. Petroleum Formation and Occurrence, 2nd edition. SpringerVerlag, New York, 699 pp.

van Dongen, B.E., Schouten, S., Sinninghe Damsté, J.S., 2003. Sulfurization of carbohydrates results in a S-rich, unresolved complex mixture in kerogen pyrolysates. Energy and Fuels 17, 1109-1118.

van Dongen, B.E., Schouten, S., Sinninghe Damsté, J.S., 2006. Preservation of carbohydrates through sulfurization in a Jurassic euxinic shelf sea: Examination of the black stone band TOC cycle in the Kimmeridge Clay Formation, UK. Organic Geochemistry 37, 1052-1073.

Viollier, E., Michard, G., Jézéquel, D., Pèpe, M., Sarazin, G., 1997. Geochemical study of a crater lake: Lake Pavin, Puy de Dôme, France. Constraints afforded by the particulate matter distribution in the element cycling within the lake. Chemical Geology 142, 225241.

Werne, J.P., Hollander, D.J., Behrens, A., Schaeffer, P., Albrecht, P., Sinninghe Damsté, J.S., 2000. Timing of early diagenetic sulfurization of organic matter: a precursor-product relationship in Holocene sediments of the anoxic Cariaco Basin, Venezuela. Geochimica et Cosmochimica Acta 64, 1741-1751. 


\section{Highlights}

-Organo-clay interactions in situ using montmorilllonite (Na MMt) and kaolinite (Kaol).

-Excessive DOC concentration in sample proximal water, interpreted as effect of clay attraction.

-Fatty acids main reactive lipid group with Na MMt and Kaol.

-Water column oxygenic/anoxic transition zone most propitious zone for organo-clay interaction.

-Swelling clay interlayer spacing growth occurred, but not attributed to organic intercalation. 


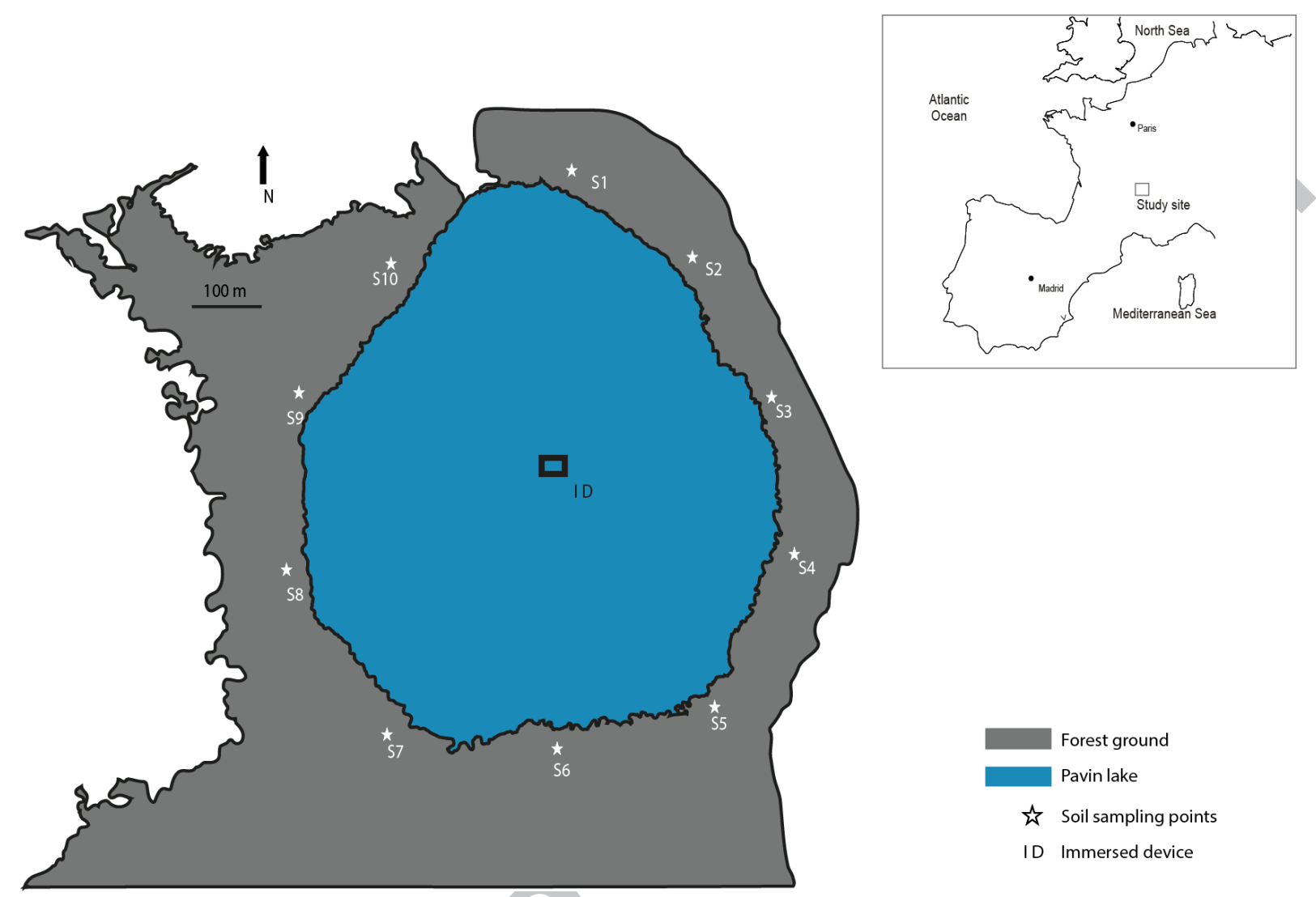



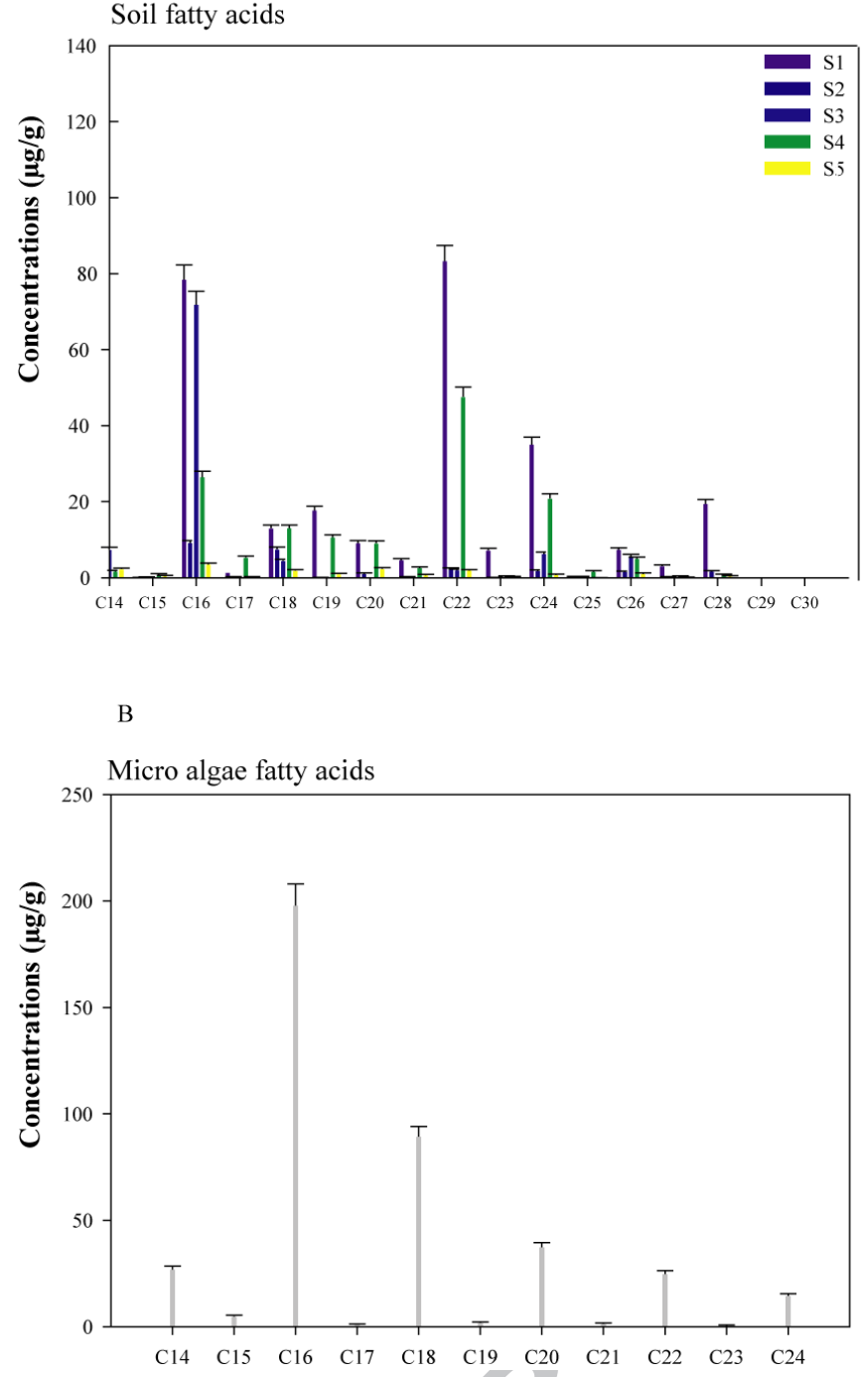

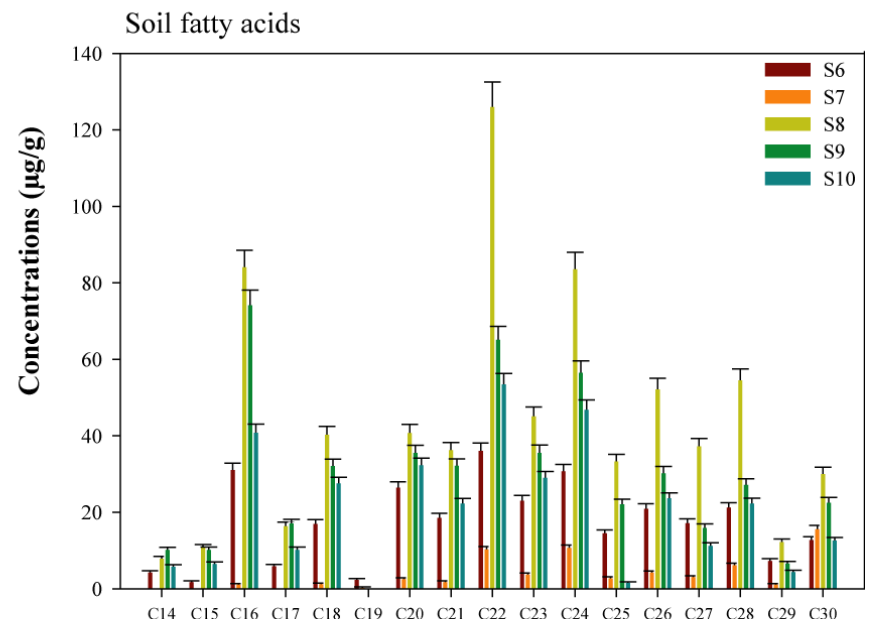



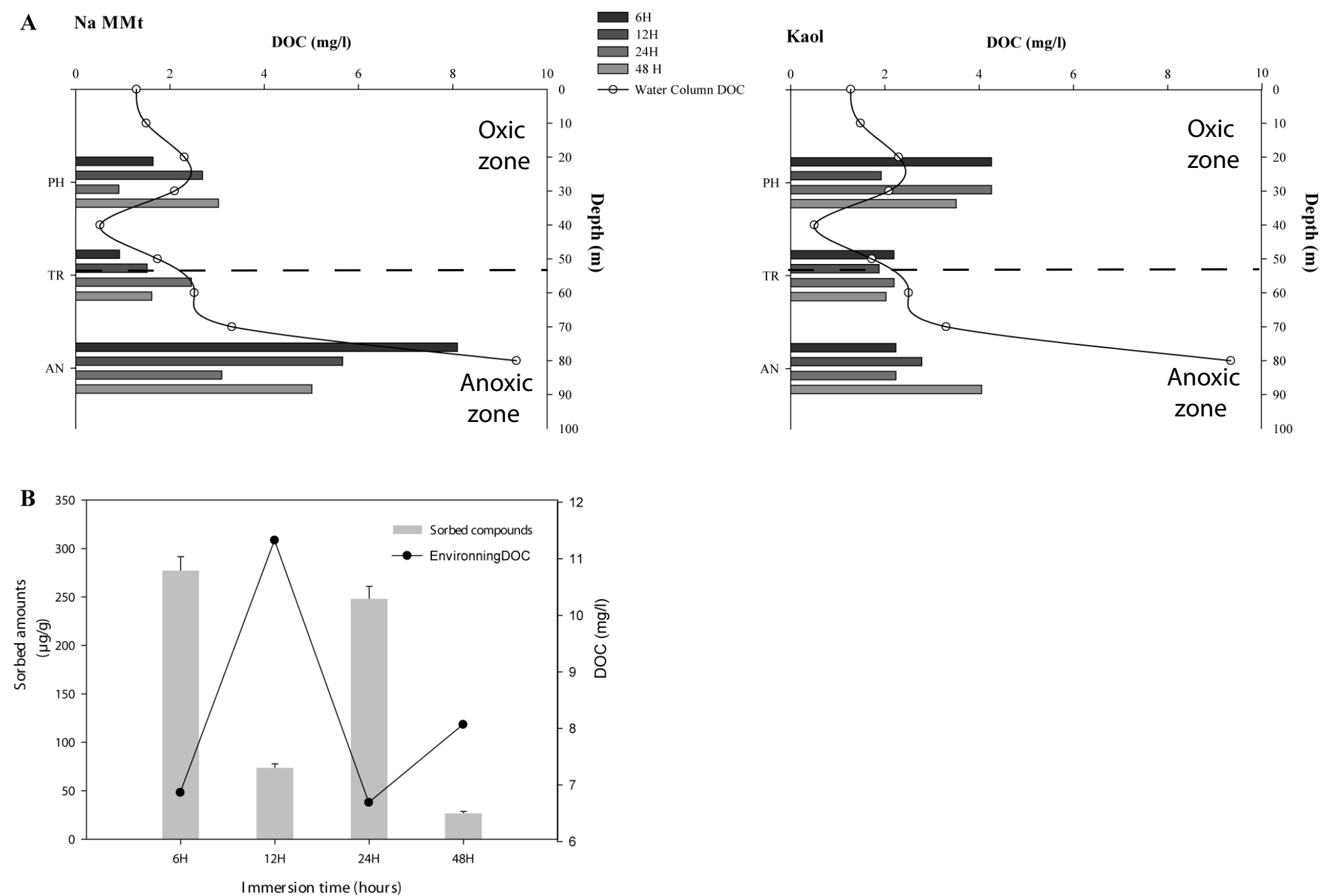
Before algal bloom

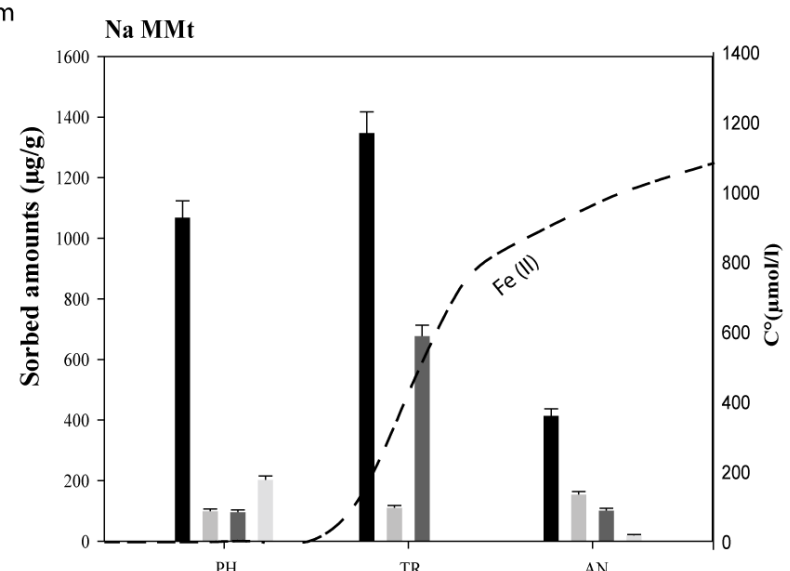

After algal bloom

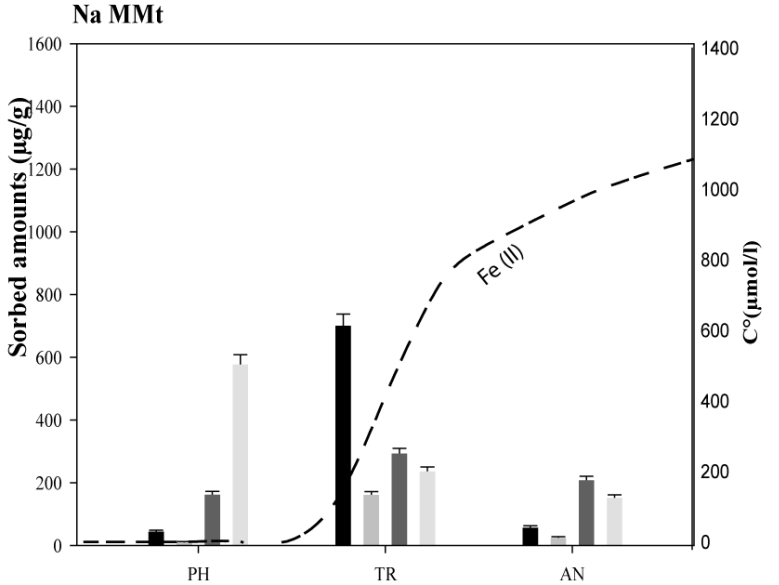

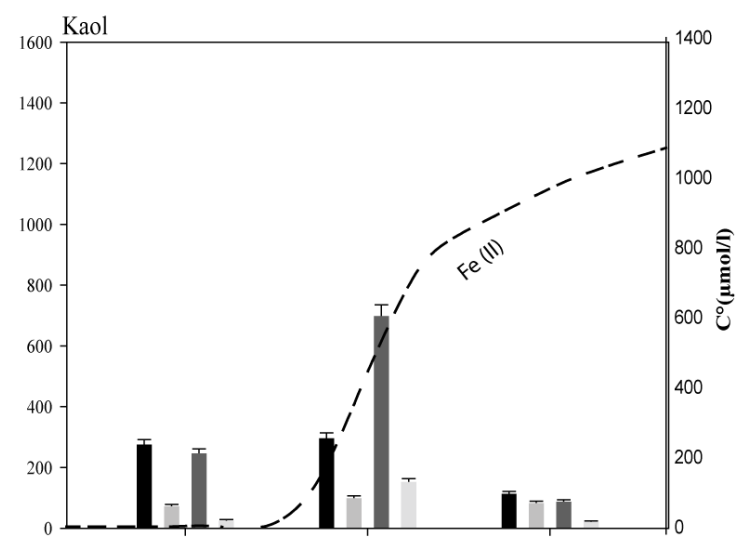

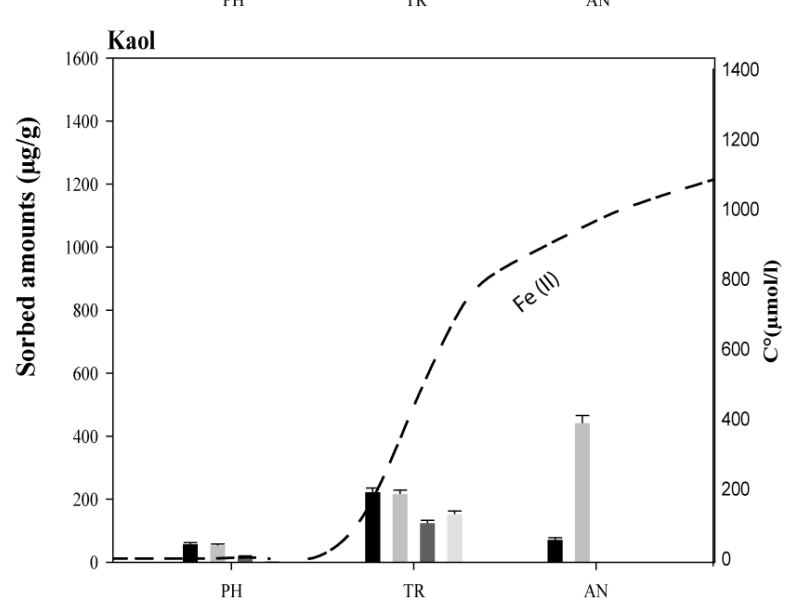

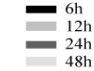



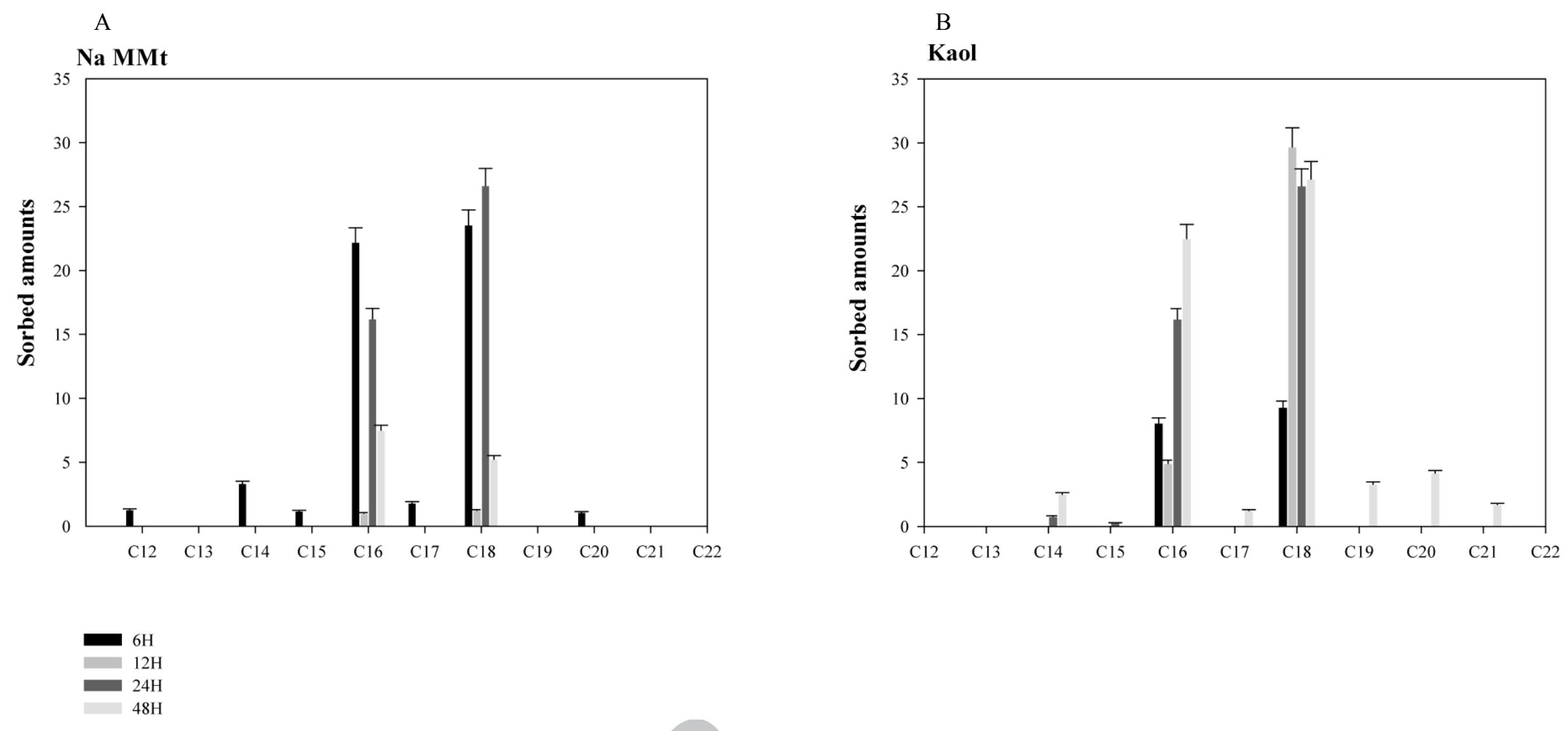
Not immersed
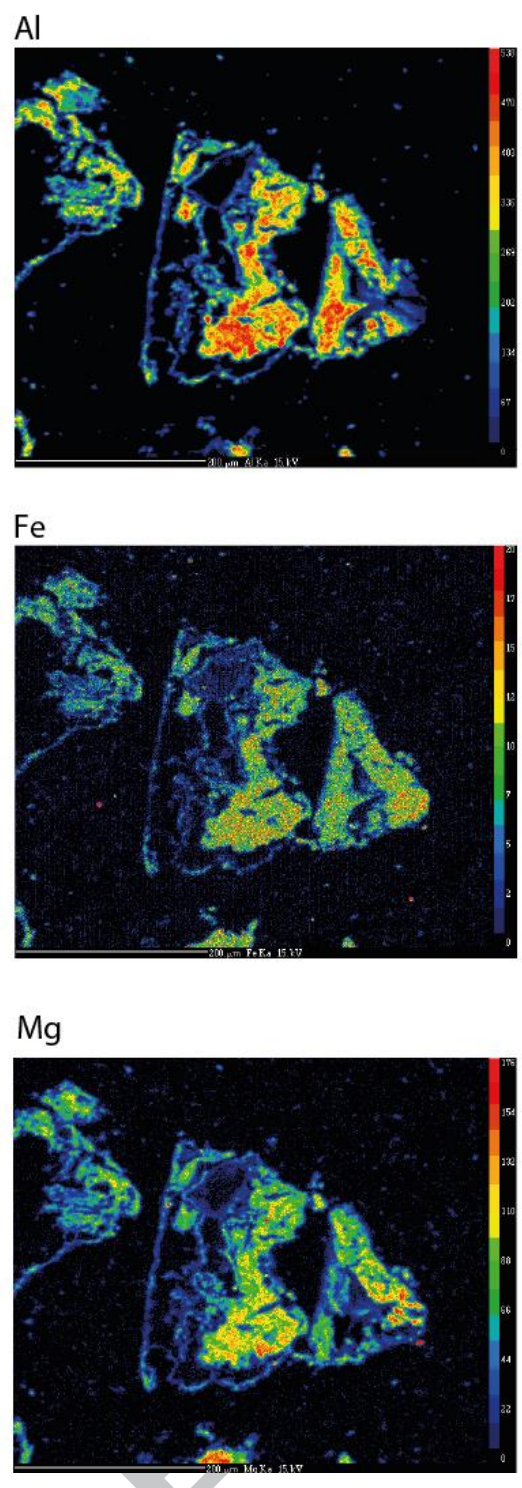


\section{A}
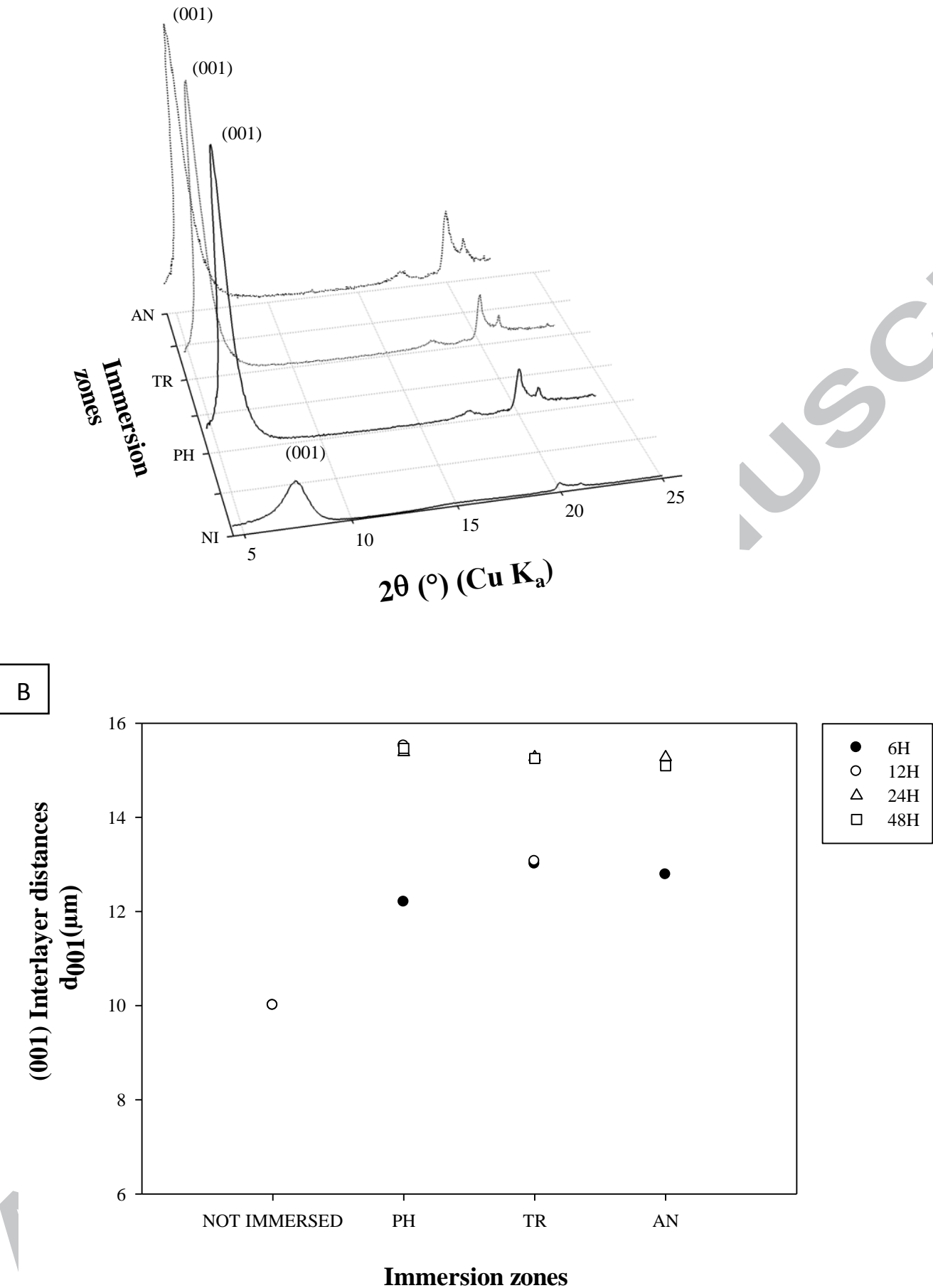